\title{
A GEOGRAFIA DA ACUMULAÇÃO E DAS CRISES CAPITALISTAS EM DAVID HARVEY
}

\author{
the geography of accumulation and the capitalist crisis in David Harvey
}

Gilberto Cunha Franca*

RESENHA DE: HARVEY, D. O enigma do capital e as crises do capitalismo. Tradução de João Alexandre Peschanski. São Paulo, Boitempo, 2011. 237 p.

O livro de David Harvey, O Enigma do capital, é reconhecidamente uma das análises mais instigantes da crise atual. O "livro é sobre o fluxo do capital" (p.7), diz no preâmbulo o autor, que nos conduz pelas tendências deste fluxo enquanto revela, também, como o capital, a cada passo de sua acumulação, levanta suas próprias barreiras. Estes passos são apresentados em contextos histórico-geográficos ao longo de oito capítulos e dois apêndices com o cronograma das principais crises e inovações financeiras desde a década de 1970. Cabe lembrar que Harvey tem inúmeros livros e artigos publicados no Brasil, como Condição pós-moderna (1994) e Produção capitalista do espaço (2005), além do recém publicado (por enquanto em inglês) A cidade rebelde: do direito à cidade à revolução urbana (2012).

No capítulo 1, A crise, o autor descreve a crise imobiliária de 2008 nos EUA e o contágio incontrolável de outros lugares e setores da economia mundial. Novamente, a urbanização esteve no centro das conexões financeiras que envolvem crédito de alto risco e hipotecas, como sustentáculo de uma busca interminável de crescimento acumulado de capital. De 1973 a 2009 o PIB mündial passou de 16 trilhões a 56,2 trilhões. O problema maior é apontar quais serão as saídas lucrativas capazes de retomar taxas médias de $3 \%$ crescimento do PIB mundial, para absorver os excedentes de capital. Mas por que 3\% de crescimento pressupõem 3\% um reinvestimento? Este é o enigma que o autor procura revelar.

Por que o capitalismo vive sucessivas crises? Esta é a questão do capítulo 2, O capital reunido, que Harvey descreve como "problema de absorção dos excedentes" (p.45). Em termos teóricos o problema se coloca da seguinte maneira: quanto maior a acumulação, decorrente da remoção de barreiras, maior a necessidade de descobrir novos campos de atividade para absorver o capital acumulado.

Ao reconstituir a atual crise, Harvey explica no capítulo O capital vai ao trabalho, como as barreiras postas pelo trabalho foram removidas, a partir dos anos 70, para reverter a tendência de queda dos lucros nos EUA e seguir a acumulação. Tal remoção se apoiou na combinação de inovação tecnológica e deslocamento geográfico da produção, e elevou o exército de reserva e a proletarização, com destaque para a incorporação especial de milhões de assalariados da China. $\mathrm{O}$ resultado mais geral foi uma repressão salarial e um disciplinamento da força de trabalho em escala global. Entretanto, a expansão capitalista não deixou de recolocar - e de maneira ampliada - novos problemas para a acumulação: o esgotamento de determinadas relações com a natureza; a expansão do proletariado sobre o meio ambiente construído, principalmente das grandes cidades; e as dificuldades para absorver as ondas de inovação de produtos, sobre ondas de inovações tecnológicas.

(*) Prof. Dr. do Curso de Licenciatura em Geografia da Universidade Federal de São Carlos - Campus Sorocaba, Rodovia João Leme dos Santos (SP-264), Km 110 , CEP: 18052-780, Sorocaba, (SP), Brasil, Tel: (+55 15) 32296006 - gfranca@usp.br 
A segunda grande barreira a ser transposta foi o consumo, assunto do capítulo 4, O capital vai ao mercado. Harvey explica como o crédito entrou para estimular o consumo e, principalmente, o consumismo norte americano, num contexto de massa salarial rebaixada. Sobre este paradoxo, elevou-se a crença de que, por meio do crédito, o excedente de hoje pudesse sempre ser reinvestido amanhã, até que as condições reais de renda da população e os negócios financeiros com hipotecas ficassem distantes e descompassados demais.

No capítulo 5, O capital evolui, Harvey discute como o capitalismo evoluiu transformando suas esferas de atividade. Nos últimos 30 anos, cidades como Shenzhen, na China, revolucionaram as relações sociais, as tecnologias, a organização do trabalho, a relação com o meio ambiente, a vida cotidiana, o arranjo político e as concepções de mundo. Estas sete esferas evoluem de maneira interligada, porém, sob o capitalismo, isto nunca ocorre harmoniosamente. Mudanças tecnológicas, por exemplo, quase sempre tem impactos no emprego, na natureza, etc. Para os movimentos políticos, o maior risco é situar-se num ponto de vanguarda, e, com isso, não enxergar a dinâmica coevolutiva das esferas de atividade, ou seja, a passagem de uma esfera à outra e a combinação diferenciada delas em certos lugares.

Em A geografia disso tudo, capítulo 6, o autor desenvolve a tese de que a propagação da crise sobre os lugares depende das relações espaciais que estes estabelecem na acumulação do capital. Harvey se apoia em dois princípios: de que o capital precisa ultrapassar todos os limites geográficos para manter a acumulação; e de que certos lugares são mais lucrativos que outros. Na busca por lugares mais lucrativos, outros são abandonados e desvalorizados, com risco de crises locais que, por sua vez, podem propagar-se em crises mais amplas, como agora. Tudo dependerá do nível e extensão das conexões espaciais estabelecidas. Nos últimos 30 anos, a urbanização e a construção de infraestruturas foram especiais nestas conexões, absorvendo e sustentando os esquemas financeiros de risco. Como diz o autor, "os investimentos no espaço construído são em geral baseados em crédito de alto risco e de retorno demorado: quando o excesso de investimento é enfim revelado (como aconteceu há pouco tempo em Dubai), o caos financeiro que levou muitos anos a ser produzido leva muitos anos para se desfazer" (p.14). Na escalada global da urbanização, esteve em curso uma escalada de desapropriações, decorrentes da valorização do espaço, movendo principalmente das áreas centrais das cidades, as populações mais pobres e vulneráveis. Mas em resistência às despossessões de todo tipo, um movimento político pelo direito a cidade, mesmo fragmentado, ganhou muito relevo entre os demais direitos humanos fundamentais.

O choque entre a lógica econômica e a lógica política e territorial é tema do capítulo 7, A destruição criativa da terra. Na construção do espaço, que alimenta a fluidez requerida pela circulação capitalista, também se constroem configurações territoriais relativamente fixas, como lugares, regiões. Através de suas associações políticas, estas geografias se defendem como podem das reconfigurações destrutivas do capital. Por outro lado, apesar da relativa fixidez, as fronteiras políticas também são redefinidas. Basta ver como se alterou o mapa dos Estados nacionais, das comunidades urbanas e rurais, e dos blocos supraestatais. Na crise, aumentam estas tentações geopolíticas, como nesta recente ofensiva do EUA no Oriente Médio para evitar que a região e o petróleo fujam de seu controle. O desfecho, entretanto, dependerá muito do poder internalizado por outros países, sobretudo pela China, e da evolução da resistência popular, como a Primavera Árabe.

No último capítulo, Que fazer e quem vai fazê-lo? temos a teoria correvolucionária de Harvey, cujo princípio é "manter o movimento político movendo-se de uma esfera de atividade para outra, de maneira que se reforçam mutuamente" (p.185). O centro político desta visão é enfrentar o crescimento interminável da acumulação e assumir o controle social sobre a produção e a distribuição dos excedentes. O sujeito social se divide em dois grandes grupos: os indignados e os despossuídos. Os indignados incluem os intelectuais críticos, a massa da juventude, mulheres, grupos étnicos e locais em movimento. O grupo dos despossuídos compreende o proletariado e os expropriados do campo e das cidades. Existem sérias dificuldades para que estes grupos sociais se unifiquem, aponta 
o autor, mas que não impediram que estes protagonizassem lutas em cinco campos organizativos: das ONGs; dos grupos autonomistas; da organização do trabalho e dos partidos de esquerda; dos movimentos sociais; e também dos movimentos em torno da identidade (gênero, raça, etnia, infância) e do meio ambiente.

O autor é bastante crítico à atuação de alguns destes grupos, sobretudo os três primeiros. Mas, por vezes, enxerga neles alguma importância na permanente revolução de todas as esferas de atividade. A força da visão correvolucionária apresentada por Harvey vem seguramente de uma leitura bem particular das ideias de Marx. Pode-se dizer, inclusive, que o Enigma do capital foi escrito para dizer que Marx estava certo sobre as crises capitalistas. Mas isto não resume, evidentemente, a importância do livro. Há algo de muito original em sua explicação de como a geografia e a urbanização, em particular, se tornaram fundamentais tanto para a formação quanto para a solução das crises. E por conta disso, nos dá muito argumento de que evolução da luta de classes passa por esta compreensão, a começar pelo esclarecimento do enigma do capital. Mas isto não basta, porque "a acumulação capitalista nunca vai cessar. Terá que ser interrompida. A classe capitalista nunca vai entregar voluntariamente seu poder. Terá de ser despossuída” (p.209). 